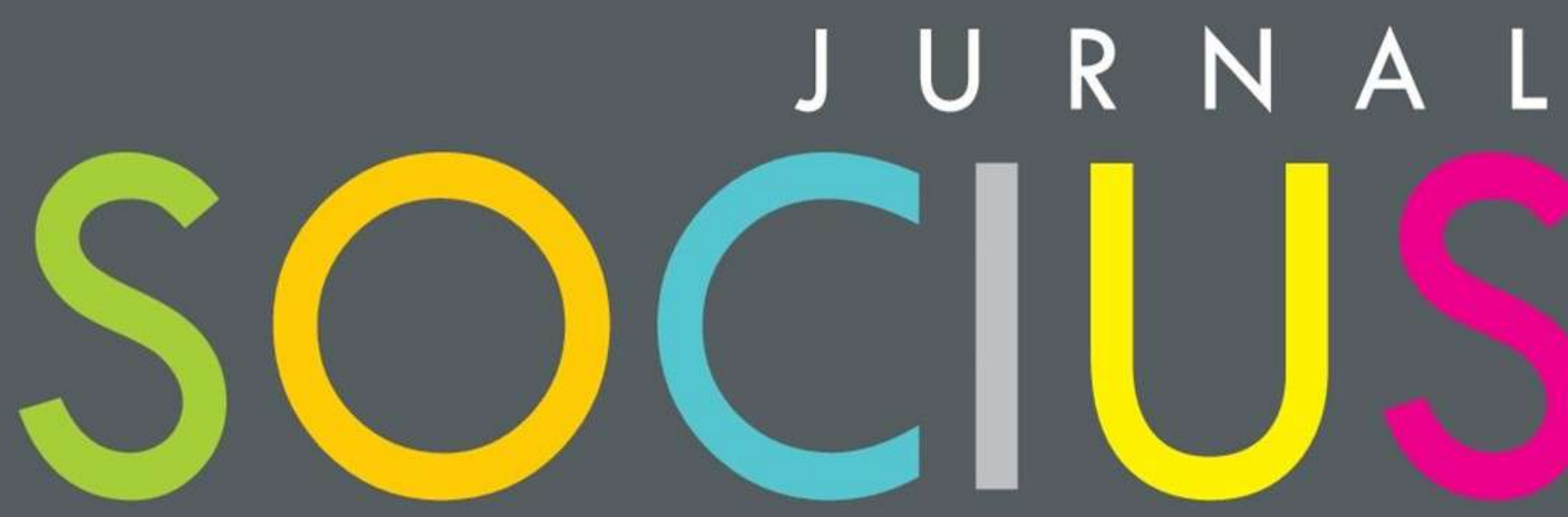

Journal of Sociology Research and Education

DITERBITKAN OLEH :

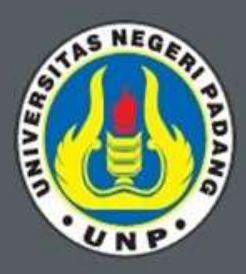

$\angle A B O R$

JURUSAN SOSIOLOGI FAKULTAS ILMU SOSIAL UNIVERSITAS NEGERI PADANG

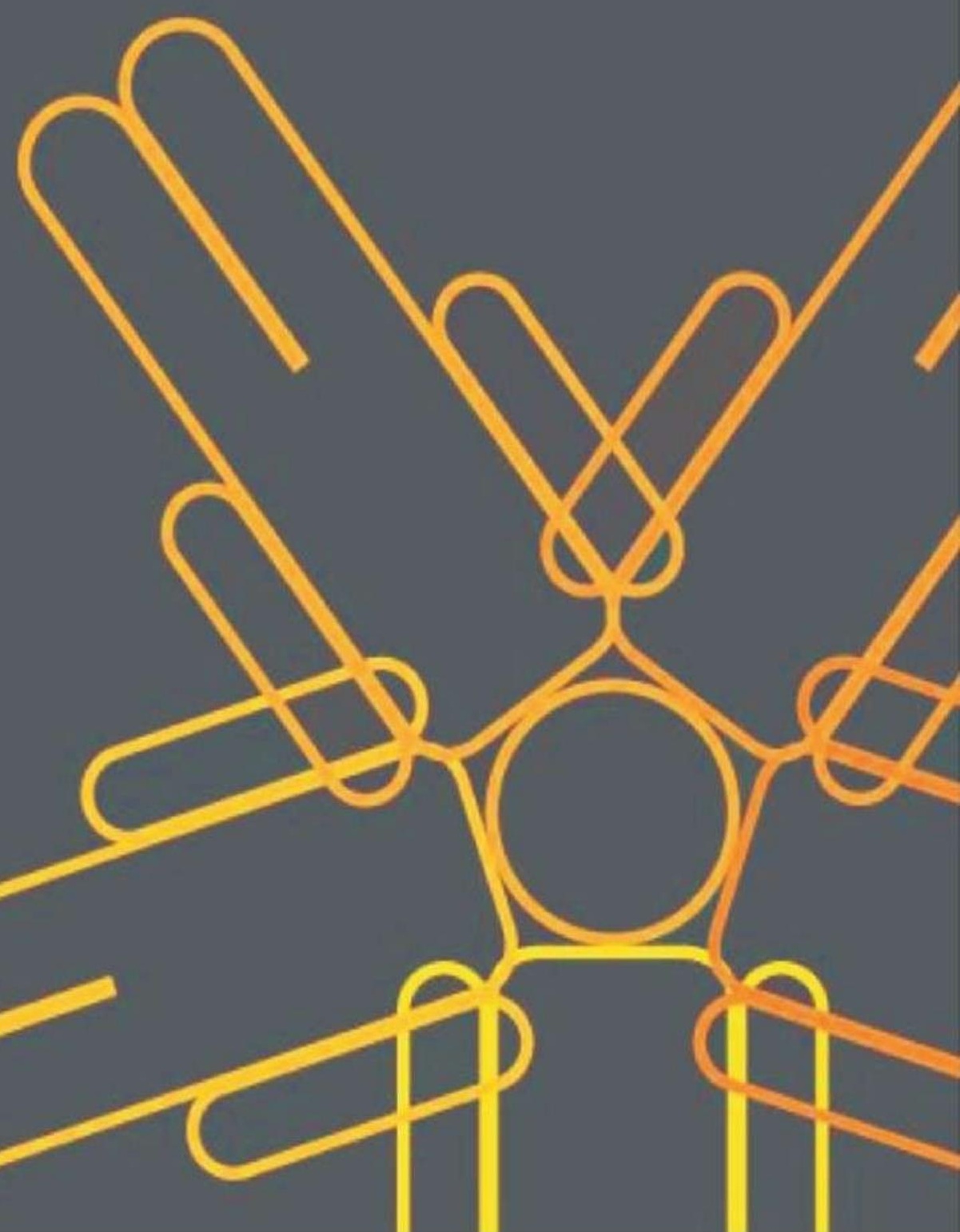




\section{SOCIUS}

Vol. 7, No. 2, Th. 2020

ISSN : 2356-4180 (cetak)

2442-8663 (online)

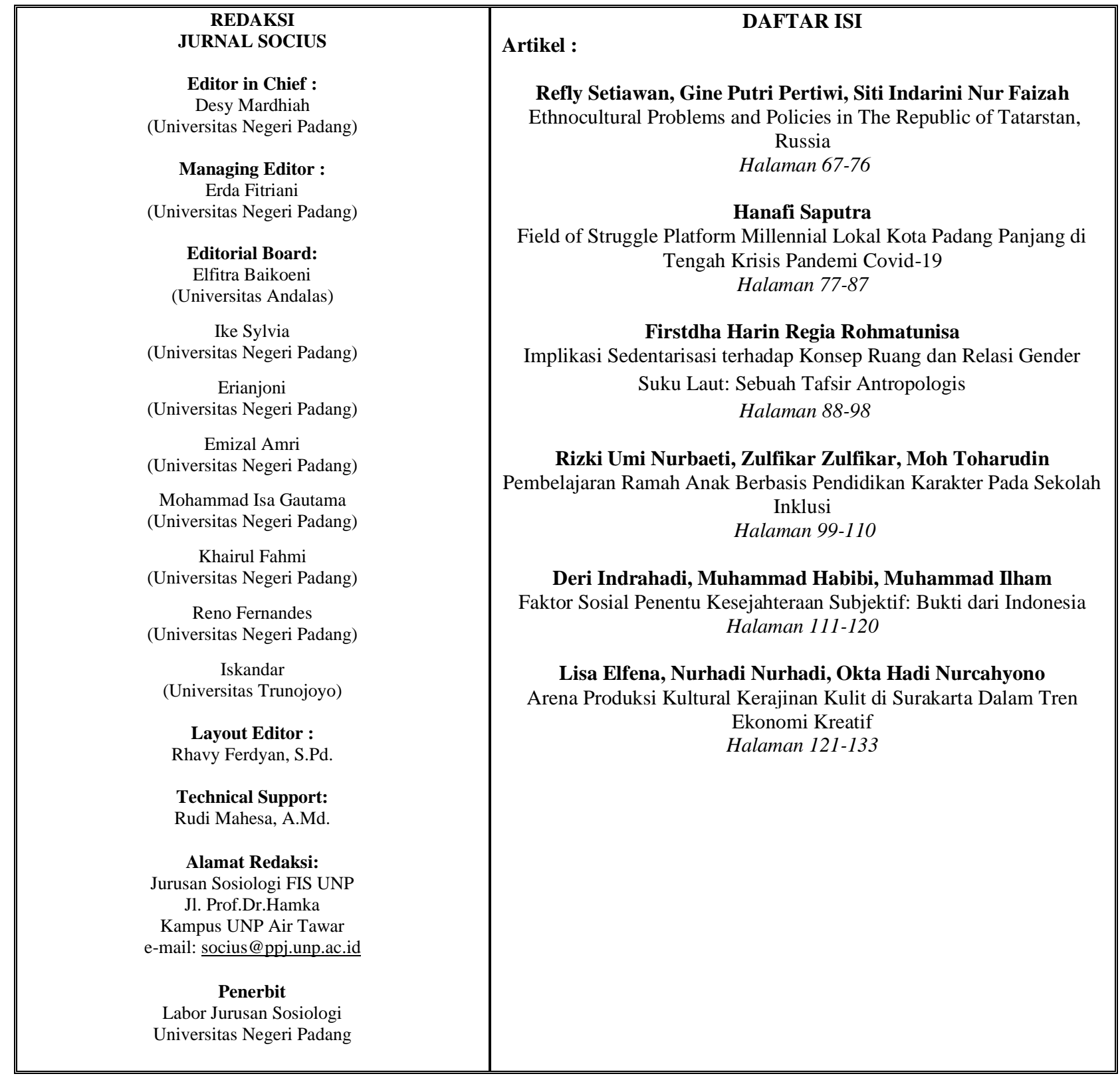




\title{
Pembelajaran Ramah Anak Berbasis Pendidikan Karakter Pada Sekolah Inklusi
}

Rizki Umi Nurbaeti ${ }^{1}$, Zulfikar Zulfikar ${ }^{2}$, Moh. Toharudin ${ }^{3}$

1,2,3 Universitas Muhadi Setiabudi

Email: rizkiuminurbati@gmail.com, fikartakalar@gmail.com, sunantoha12@gmail.com

\begin{abstract}
Abstrak
Artikel ini bertujuan untuk mendeskripsikan pembelajaran ramah anak berbasis pendidikan karakter di sekolah inklusi, dimulai dari perencanaan, implementasi, dan evaluasi pembelajaran. Penelitian menggunakan metode kualitatif untuk menganalisis aktivitas pembelajaran di sekolah inklusi. Pengumpulan data dilakukan dengan wawancara, observasi dan dokumentasi. Tahapan dalam penelitian terdiri dari tiga tahap, tahap pra lapangan, tahap pekerjaan lapangan, dan tahap analisis data. Hasil penelitian menunjukkan bahwa manajemen pembelajaran ramah anak terjadi melalui beberapa proses yaitu : (1) Tahap perencanaan guru menyusun RPP yang ramah anak, tidak mengandung unsur kekerasan, pornografi dan terorisme; (2) Tahap pelaksanaan ditunjukkan dengan adanya proses pembelajaran yang aktif, kreatif dan menyenangkan (PAKEM) serta bebas dari perlakuan diskriminatif, pemberian sanksi dan hukuman yang bisa membuat peserta didik merasa mendapat kekerasan baik fisik maupun psikis. Adanya kegiatan ekstrakurikuler dan kegiatan siswa lainnya untuk pengembangan minat, bakat dan kreatifitas peserta didik, dan adanya budaya senyum, salam, sapa, sopan dan santun bagi semua warga sekolah; dan (3) Tahap evaluasi dilakukan oleh guru dengan mengukur kemampuan belajar dengan memperhatikan pencapaian tujuan, tingkat penguasaan siswa, dan memberikan nilai kepada siswa sebagai laporan hasil belajar di sekolah tanpa diskriminasi; upaya untuk meningkatkan pembelajaran ramah anak yaitu dengan membudayakan 5S senyum, sapa, salam, sopan dan santun. Selain itu juga menerapkan 7K, yaitu: keamanan, ketertiban, kegotongroyongan, kebersihan, keindahan, kekeluargaan, dan kerindangan.
\end{abstract}

\section{Kata Kunci: sekolah Inklusi, pembelajaran, ramah anak, pendidikan karakter}

\begin{abstract}
This article aims to describe character education-base child-friendly learning in inclusive schools, from the planning, implementation and evaluation stages of learning. This research uses qualitative methods to analyze learning activities in inclusive schools. Data collection was carried out by interview, observation and documentation. The stages in the research consisted of three stages, the pre-field stage, the fieldwork stage, and the data analysis stage. The results showed that child-friendly learning management occurs through several processes, namely: (1) The planning stage of the teacher compiles child-friendly lesson plans, does not contain elements of violence, pornography and terrorism; (2) The implementation stage is indicated by the existence of an active, creative and fun learning process (PAKEM) and is free from discriminatory treatment, the provision of sanctions and punishments that can make students feel that they are subject to both physical and psychological violence. The existence of extracurricular activities and other student activities to develop students' interests, talents and creativity, and a culture of smiles, greetings, greetings, courtesy and courtesy for all school members; and (3) the evaluation stage is carried out by the teacher by measuring the ability to learn by taking into account the achievement of goals, the level of student mastery, and giving grades to students as a report on learning outcomes in schools without discrimination; efforts to improve child-friendly learning, namely by cultivating $5 \mathrm{~S}$ smiles, greetings, greetings, courtesy and courtesy. Besides that, it also applies 7K, namely: security, order, mutual cooperation, cleanliness, beauty, kinship, and shade.

Keyword: inclusive school, learning, child friendly, character education
\end{abstract}

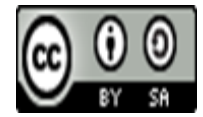

Received: October 23, 2020

Revised: November 24, 2020

Available Online: December 21, 2020 


\section{Pendahuluan}

Pendidikan Nasional berfungsi mengembangkan kemampuan dan membentuk karakter serta peradaban bangsa yang bermartabat dalam rangka mencerdaskan kehidupan bangsa (UU Sisdiknas No. 20 tahun 2003). Pembangunan karakter merupakan upaya perwujudan amanat Pancasila dan Pembukaan Undang-Undang Dasar 1945. Thomas Lickona dalam (Marzuki, 2012) mendefiniskan karakter adalah "a reliable inner dispotion to respond to situations in a morally good way. Character so conveived has three interrelated parts, moral knowing, moral feeling, and moral behaviour". Pendidikan karakter bersumber dari agama, Pancasila, budaya, Undang-Undang Dasar 1945 dan tujuan pendidikan nasional. Pelaksanaan pendidikan karakter memiliki beberapa permasalahan, yaitu adanya ketidaksinkronan antara konsep pelaksanaan pendidikan karakter di sekolah dengan realita yang dihadapi di lingkungan masyarakat. Pada saat pembelajaran di sekolah diajarkan nilai-nilai karakter baik, sementara kondisi lingkungan masyarakat tidak menerapkannya.

Pendidikan karakter dilaksanakan hampir pada semua jenjang pendidikan, tidak terkecuali pada sekolah inklusi. Pendidikan inklusi sendiri merupakan solusi pemerintah dalam menyediakan layanan pembelajaran untuk anak-anak berkebutuhan khusus supaya dapat belajar bersama dengan teman seusia mereka di sekolah reguler. Melakukan pendidikan inklusi menuntut sekolah untuk melakukan penyesuaian dalam hal kurikulum, fasilitas dan infrastruktur pendidikan, serta sistem pembelajaran yang disesuaikan dengan kebutuhan individu peserta didik (Direktorat Pendidikan Luar Biasa, 2007). Untuk memenuhi kebutuhan pembelajaran bagi anak berkebutuhan khusus, maka program pendidikan inklusi telah diprogramkan sejak dini melalui sekolah dasar.

Sekolah dasar merupakan tempat untuk menanamkan dan mengembangkan nilai-nilai karakter siswa (tata krama) melalui pengkondisian yang dilakukan oleh guru di lingkungan sekolah. Pengkondisian dilakukan agar lingkungan sekolah dapat menjadi tempat yang kondusif untuk menumbuhkan dan mengembangkan karakter optimisme, mengembangkan penalaran, mencerahkan pikiran, memberikan keterampilan dan sikap yang dibutuhkan untuk membuat siswa memiliki kejujuran, sopan santun, kreativitas, produktivitas, kemandirian, dan saling menguntungkan. Suatu jenis pembelajaran yang memungkinkan siswa untuk memiliki nilai karakter diwujudkan melalui manajemen pembelajaran yang ramah anak. Guru sebagai komunitas belajar menempatkan siswa sebagai pusat pembelajaran dengan mendorong partisipasi siswa dalam belajar, memahami dan memanfaatkan media pembelajaran adaptif, dan juga memiliki minat untuk memberikan layanan terbaik bagi siswa.

Berdasarkan data tahun 2018 yang tercatat di Dinas Pendidikan Kabupaten Brebes terdapat 1.304 anak berkebutuhan khusus. Sebanyak 153 anak berkebutuhan khusus tersebut menempuh pendidikan di sekolah inklusi di Kabupaten Brebes, 13 diantara mereka saat ini sekolah di SDN Sawojajar 01 Brebes. Dari observasi yang dilakukan, anak-anak tersebut mengalami berbagai masalah dalam kegiatan pembelajaran, mencakup keterlambatan dalam belajar dan masalah emosional. Masalah pembelajaran juga terjadi karena berbagai keterbatasan yang terdapat pada guru yang mengajar seperti tingkat kompetensi guru yang rendah, sehingga mengalami kendala dalam modifikasi kurikulum dan manajemen pembelajaran.

Keterbatasan ini berakibat pada kurangnya pemahaman guru dalam melaksanakan proses pembelajaran inklusi Hal ini sejalan dengan hasil penelitian yang meneliti sistem dukungan dalam menerapkan pendidikan inklusi (Valeo, 2008). Mereka menemukan bahwa ada perbedaan persepsi antara guru dan administrator dalam menerapkan pendidikan inklusi. Para guru merasa frustrasi karena tuntutan kurikulum inklusi yang sulit mereka pahami. Atas dasar berbagai permasalahan di atas maka dilakukan peningkatan manajemen pembelajaran ramah 
anak di SD Negeri Sawojajar 01 Brebes. Sekolah ini menjadi model penyelenggaraan program pendidikan bagi anak berkebutuhan khusus dimana penyelenggaraanya dipadukan bersama anak normal dengan menggunakan kurikulum yang disesuaikan dengan kondisi anak.

Menurut Suharno (2008:19) manajemen pembelajaran merupakan bagian dari manajemen sekolah (Suharno, 2008), sedangkan manajemen kesiswaan adalah suatu kegiatan pencatatan siswa dari proses penerimaan sampai siswa tersebut lulus dari sekolah melalui program ektrakurikuler dan kurikuler (Marno \& Supriyanto, 2008). Selanjutnya, Mulyasa (2009) mendefinisikan manajemen kesiswaan adalah pengaturan terhadap kegiatan yang berkaitan dengan siswa, dari masuk sampai keluarnya siswa tersebut dari suatu sekolah. Manajemen kesiswaan tidak hanya berhubungan dengan data siswa, melainkan adanya aspek lain yang dapat membantu mengembangkan keterampilan siswa (Mulyasa, 2009).

Pembelajaran ramah anak bertujuan untuk memberikan motivasi kepada siswa, belajar menggunakan media yang sesuai dengan kebutuhan siswa, menerapkan metode pembelajaran yang melibatkan siswa, memberikan contoh nyata yang diketahui siswa. Sedangkan nilai-nilai karakter yang diberikan kepada siswa berupa perlakuan yang adil, penerapan norma agama, norma sosial dan budaya lokal, kasih sayang, dan saling menghormati (Toharudin, Florentinus, T. S., Ekosiswoyo, \& Sutarto, 2018). Sebagaimana yang telah dijelaskan dalam UU KPPPA Nomor 11 Tahun 2011 tentang Kebijakan Pengembangan Kabupaten/ Kota Layak Anak.

Berdasarkan evaluasi pelaksanaan KLA di Kabupaten Brebes Tahun 2015, indikator sekolah ramah anak di Kabupaten Brebes perlu ditingkatkan dengan mengembangkan model sekolah ramah anak. Strategi percepatan pengembangan KLA di Kabupaten Brebes Tahun 2016-2019 adalah Pengembangan Sekolah Ramah Anak di Kabupaten Brebes. Untuk itu, perlu disusun petunjuk pelaksanaan pengembangan model sekolah ramah anak melalui Standar Operasional Pengembangan Model Sekolah Ramah Anak di Kabupaten Brebes. Salah satu sekolah yang konsisten menjalankan program ini adalah SDN Sawojajar 01 Brebes, dengan melaksanakan pembelajaran ramah anak melalui tahap perencanaan, pelaksanaan dan evaluasi secara kontinu.

Tujuan dari penelitian ini adalah untuk mendeskripsikan pembelajaran ramah anak berbasis pendidikan karakter pada sekolah inklusi di SDN Sawojajar 01 Brebes. Temuan ini dianalisis melalui tiga proses pelaksanaan yaitu tahap perencanaan, implementasi, dan evaluasi pembelajaran ramah anak. Kajian ini penting untuk dilakukan mengingat pembelajaran ramah anak menjadi salah satu faktor pendukung keberhasilan pendidikan karakter di sekolah inklusi. Selain itu penelitian terkait pembelajaran ramah anak di sekolah inklusi masih sangat terbatas. Studi sebelumnya lebih banyak mengkaji tentang pembelajaran ramah anak di sekolah formal biasa (Yuliasih, 2012). Dengan demikian tulisan ini memberikan kontribusi baru bagi studi tentang pembelajaran ramah anak berbasis pendidikan karakter di sekolah inklusi.

\section{Metode Penelitian}

Penelitian ini menggunakan pendekatan kualitatif dengan tipe studi kasus. Pendekatan ini dipilih karena dinilai dapat menggali berbagai data yang sesuai dengan tujuan penelitian di sekolah dasar ramah anak, yaitu data tentang perencanaan pembelajaran ramah anak di sekolah dasar inklusi, pelaksanaan pembelajaran ramah anak di sekolah inklusi, dan evaluasi pembelajaran ramah anak di sekolah inklusi. Penelitian ini dilaksanakan di SD Negeri Sawojajar 01 Kecamatan Wanasari Kabupaten Brebes. Pertimbangan pengambilan lokasi penelitian adalah berdasarkan pengamatan peneliti bahwa SD Negeri Sawojajar 01 Brebes sebagai sekolah yang ditunjuk pihak Kabupaten Brebes sebagai sekolah ramah anak yang mendidik siswa berkebutuhan khusus.

Pemilihan informan dalam penelitian ini dilakukan dengan purposive sampling. Informan dalam penelitian ini adalah guru kelas I sampai kelas VI, siswa berkebutuhan khusus dan siswa 
reguler, serta kepala sekolah. Data diperoleh melalui data primer dan data sekunder. Data primer diperoleh melalui wawancara mendalam dan observasi sementara data sekunder diperoleh dari studi dokumentasi (study of documentation) yang diperoleh dari dokumen sekolah yang berhubungan dengan sekolah ramah anak. Analisis data dilakukan melalui beberapa tahap analisis, diantaranya melalui proses mengumpulkan data, reduksi data melaui proses pengkodean data, pengklasifikasian data, penyajian data dan penarikan kesimpulan (Bungin, 2011). Berikut ini gambar alur penelitian peningkatan manajemen pembelajaran ramah anak di sekolah dasar inklusi.

\section{Hasil dan Pembahasan}

\section{Sekolah ramah anak dan komitmen warga sekolah}

Sekolah Ramah Anak (SRA) diterapkan di SDN Sawojajar 01 Brebes mulai tahun 2015. Sekolah Ramah Anak di sekolah ini diselenggarakan atas dasar komitmen semua warga sekolah. Komitmen ini dibuat oleh pihak sekolah dan diketahui oleh Dinas Pendidikan Kabupaten Brebes, dihadiri oleh unsur lain dalam satuan pendidikan serta pemangku kepentingan di wilayah kecamatan. Isi komitmen penyelenggaraan Sekolah Ramah Anak di SDN Sawojajar 01 seperti berikut ini:

Kami Keluarga Besar Sekolah SD Negeri Sawojajar 01, telah berkomitmen mengembangkan sekolah ramah anak dengan menerapkan kebijakan bersama untuk dilaksanakan oleh seluruh warga sekolah sebagai berikut: (1) melaksanakan kebijakan Sekolah SD Negeri Sawojajar 01 sebagai sekolah ramah anak yaitu sekolah anti kekerasan, diskriminasi dan perlakuan salah lainnya bagi seluruh warga sekolah; (2) melaksanakan kebijakan Sekolah SD Negeri Sawojajar 01 sebagai sekolah ramah anak yaitu sebagai kawasan bebas asap rokok, bebas narkotika dan obat-obat terlarang lainnya; (3) melaksanakan kebijakan Sekolah SD Negeri Sawojajar 01 sebagai sekolah ramah anak dengan lingkungan sekolah yang bersih, sehat dan bebas dari jajan yang berbahaya dan beracun” (Dokumen SRA SDN Sawojajar 01, 2015).

Penyelenggaran Sekolah Ramah Anak di SDN Sawojajar 01 dilaksanakan oleh tim pengembang yang terdiri dari pihak sekolah dan masyarakat. Setelah seluruh warga satuan pendidikan termasuk komite sekolah dan orangtua peserta didik berkomitmen untuk mengembangkan model sekolah ramah anak, maka seluruh pemangku kepentingan di satuan pendidikan mengadakan pertemuan untuk membentuk Tim Pengembangan Model Sekolah Ramah Anak di masing-masing satuan pendidikan. Susunan Tim Pengembangan model Sekolah Ramah Anak sekurang-kurangnya adalah : (1) ketua yaitu kepala satuan pendidikan atau yang ditunjuk oleh kepala satuan pendidikan; (2) wakil ketua yaitu perwakilan dari komite sekolah atau yang berasal dari Penyatuan persepsi dan komitmen ini; (3) sekretaris yaitu dari perwakilan tenaga kependidikan; (4) koordinator Pokja Kebijakan Sekolah Ramah Anak yaitu dari guru bimbingan dan konseling atau perwakilan guru; (5) koordinator Pokja Kurikulum Pengembangan sumber daya dan sarana prasarana yaitu dari wakil kepala sekolah atau dari tenaga pendidik atau kependidikan; (6) koordinator Pokja Partisipasi Anak yaitu dari perwakilan peserta didik atau komite sekolah; (7) koordinator Pokja Partisipasi orang tua, lembaga masyarakat dan alumni yaitu perwakilan orangtua atau kelompok masyarakat. Berikut ini adalah tim pengembang Sekolah Ramah Anak di SDN Sawojajar 01.

Tim pengembangan Sekolah Ramah Anak dibentuk untuk menyusun standar operasional dan tahapan-tahapan pengembangan model sekolah ramah anak. Tim ini beranggotakan stakeholder yang terkait dengan kluster IV Kabupaten Layak Anak dan ditetapkan dengan Keputusan Kepala Dinas Pendidikan Kabupaten Brebes. Upaya SDN Sawojajar 01 dalam 
mewujudkan pembelajaran yang ramah anak yaitu dengan membudayakan $5 \mathrm{~S}$, yaitu: senyum, sapa, salam, sopan dan santun. Selain itu juga menerapkan 7K, yaitu : keamanan, ketertiban, kegotongroyongan, kebersihan, keindahan, kekeluargaan, dan kerindangan. Slogan tersebut dipampang di depan seluruh kelas. Siswa juga diajarkan untuk menerapkan perilaku hidup bersih dan menjaga lingkungan dengan cara pihak sekolah menyediakan tempat sampah di depan kelas yang membedakan sampah organik dan non organik. Selain itu MCK juga disediakan terpisah untuk siswa dan siswi di SDN Sawojajar 01.

Menurut kepala sekolah, bahwa SDN Sawojajar 01 menjadi sekolah percontohan sekolah ramah anak (SRA). Amanat ini dari Pemerintah Daerah melalui Dinas Pendidikan Pemuda dan Olahraga Kabupaten Brebes. Amanat ini memerlukan kerjasama dan keterlibatan baik dari Kepala sekolah, guru, karyawan, komite sekolah maupun peranserta dari orangtua. Sekolah ramah anak adalah sekolah yang mampu melayani semua kebutuhan anak baik dari segi akademis maupun non akademis, pengembangan keterampilan dan aktualisasi diri, serta terlindungi anak dari kekerasan baik kekerasan fisik, psikis, verbal, ataupun seksual. Kekerasan fisik misalnya menjewer telinga, mencubit, menendang maupun menampar anak. Kekerasan psikis misalnya perlakuan yang tidak adil dari seorang guru kepada siswa karena siswa kurang pandai, berkebutuhan, atau siswa nakal. Sedangkan kekerasan verbal adalah bentuk ucapan yang dapat menyakiti hati siswa, misalnya memanggil dengan sebutan si hitam karena kulitnya hitam, memberi sebutan tolol/goblok pada anak yang kurang pandai. Sekolah berusaha melengkapi semua sarana dan prasarana yang dibutuhkan dalam rangka sekolah ramah anak. Sarana yang dibutuhkan antara lain tersedianya ruang kelas yang memadai sesuai dengan jumlah siswa, penataan halaman sekolah dilengkapi dengan taman, adanya Mandi Cuci Kakus (MCK) putra dan putri secara terpisah, dan kawasan bebas asap rakok atau napza, tempat ibadah, ruang uks, ruang bermain, dan ruang praktik siswa. Dalam rangka pemenuhan sarana tersebut dibutuhkan peranserta baik dari pemerintah, sekolah, komite sekolah maupun orangtua siswa (W.KS.21-07-2020). Dalam pelaksanaan pembelajaran ramah anak di SDN Sawojajar 01 Brebes menerapkan sesuai dengan prinsip-prinsip sekolah ramah anak berikut.

\section{Tabel 1. Prinsip pembelajaran ramah anak di SDN Sawojajar 01 Brebes}

\begin{tabular}{ll}
\hline $\begin{array}{l}\text { Prinsip Pembelajaran } \\
\text { Ramah Anak }\end{array}$ & \multicolumn{1}{c}{ Deskripsi } \\
\hline Non diskriminatif & $\begin{array}{l}\text { Menjamin kesempatan setiap anak untuk menikmati hak anak } \\
\text { untuk pendidikan tanpa diskriminasi berdasarkan disabilitas, } \\
\text { gender, suku, bangsa, agama dan latar belakang orangtua }\end{array}$ \\
$\begin{array}{l}\text { Kepentingan terbaik } \\
\text { bagi anak }\end{array}$ & $\begin{array}{l}\text { Senantiasa menjadi pertimbangan utama dalam semua keputusan } \\
\text { dan tindakan yang diambil oleh pengelola dan penyelenggara } \\
\text { pendidikan yang berkaitan dengan anak didik. } \\
\text { Menciptakan lingkungan yang menghormati martabat anak dan } \\
\text { Hidup, kelangsungan } \\
\text { hidup dan }\end{array}$ \\
$\begin{array}{l}\text { perkembangan } \\
\text { Penghormatan terhadap pengembangan holistik dan terintegratif setiap anak. } \\
\text { pandangan anak }\end{array}$ & $\begin{array}{l}\text { Mencakup penghormatan atas hak anak untuk mengekspresikan } \\
\text { pandangan dalam segala hal yang mempengaruhi anak di } \\
\text { lingkungan sekolah. } \\
\text { Pengelolaan yang baik }\end{array}$ \\
$\begin{array}{l}\text { Menjamin transparansi, akuntabilitas, partisipasi, keterbukaan } \\
\text { informasi dan supremasi hukum di satuan pendidikan. }\end{array}$ \\
\hline
\end{tabular}

Sumber: Olahan Penulis 
Sementara itu berdasarkan pengamatan peneliti pada dokumen sekolah ramah anak di SDN Sawojajar 01 Brebes, bahwa pelaksanaan kurikulum dan proses belajar mengajar yang ramah anak mulai dari anak masuk gerbang sekolah hingga pulang sekolah, termasuk hingga selesai kegiatan ekstrakurikuler. Berikut ini Adanya dokumen kurikulum di satuan pendidikan yang berbasis hak anak: (1) adanya rencana pelaksanaan pembelajaran (RPP) yang ramah anak (antara lain tidak mengandung unsur kekerasan, pornografi dan terorisme); (2) adanya Proses pembelajaran yang aktif, kreatif dan menyenangkan (PAKEM) serta bebas dari perlakuan diskriminatif, pemberian sanksi dan hukuman yang bisa membuat peserta didik merasa mendapat kekerasan baik fisik maupun psikis; (3) adanya kegiatan ekstrakurikuler dan kegiatan siswa lainnya untuk pengembangan minat, bakat dan kreatifitas peserta didik; dan (4) adanya budaya senyum, salam, sapa, sopan dan santun bagi semua warga sekolah.

Dalam pelaksanaan pembelajaran ramah anak tentunya didukung oleh sarana dan prasarana yang ramah terhadap anak. Adapun sarana dan prasarana pembelajaran ramah anak di SDN Sawojajar 01 Brebes adalah sebagai berikut: adanya ruang kelas yang memiliki kapasitas sesuai jumlah peserta didik, memiliki ventilasi yang cukup dan penerangan yang baik; ruang UKS yang sesuai standar dan digunakan oleh peserta didik; ruang perpustakaan yang memadai dan digunakan aktif oleh peserta didik; ruang konseling bagi peserta didik; kantin sehat yang berada di dalam lingkungan sekolah (tidak berada di luar pagar sekolah); ruang bermain, ruang kreativitas dan sarana olahraga bagi peserta didik; toilet yang bersih dan aman, jumlahnya memadai dan terpisah laki-laki dan perempuan serta tersedia tempat sampah untuk toilet perempuan; tempat cuci tangan pakai sabun (CTPS) di beberapa suduk sekolah; tempat sampah yang terpilah di depan setiap ruang kelas; slogan, papan himbauan dan peringatan kebijakan-kebijakan sekolah di tempat-tempat yang terlihat oleh seluruh warga sekolah.

Evaluasi dilakukan oleh tim pengembangan model sekolah ramah anak Kabupaten Brebes dan tim pengembangan model sekolah ramah anak di masing-masing satuan pendidikan sebagai berikut: (1) Evaluasi pelaksanaan pengembangan model sekolah ramah anak dilakukan oleh tim pengembangan model sekolah ramah anak di masing-masing satuan pendidikan 3 (tiga) bulan sekali. Hasil evaluasi didokumentasikan untuk dilaporkan kepada tim pengembangan model sekolah ramah anak setiap 6 (enam bulan sekali); (2) Evaluasi pelaksanaan pengembangan model sekolah ramah anak dilakukan oleh tim pengembangan model sekolah ramah anak Kabupaten Brebes di seluruh satuan pendidikan 6 (enam) bulan sekali. Hasil evaluasi didokumentasikan untuk dilaporkan kepada Koordinator Kluster IV Gugus Tugas KLA Kabupaten Brebes yaitu Dinas Pendidikan Pemuda dan Olahraga Kabupaten Brebes 1 (satu) tahun sekali. (3) Laporan hasil evaluasi pelaksanaan pengembangan model sekolah ramah anak akan dievaluasi kembali oleh Kluster IV Gugus Tugas KLA Kabupaten Brebes untuk dilakukan evaluasi dan perbaikan program dan kegiatan pemerintah daerah untuk mendukung pelaksanaan pengembangan model sekolah ramah anak di Kabupaten Brebes.

\section{Perencanaan pembelajaran ramah anak}

Perencanaan pembelajaran adalah suatu kegiatan yang direncanakan dalam hubungannya dengan proses belajar mengajar atau pembelajaran untuk mengembangkan, evaluasi dan memelihara situasi dengan fasilitas pendidikan guna pencapaian tujuan pembelajaran. Perencanaan dalam bahasa Inggris planning merupakan kegiatan yang dikonsep sebelum melaksanakan kegiatan untuk mencapai tujuan tertentu. Berdasarkan hasil wawancara bahwa perencanaan pembelajaran ramah anak di sekolah inklusi ditemukan guru menyusun Rencana Pelaksanaan Pembelajaran dan silabus pembelajaran pada awal tahun ajaran baru yang mengacu pada kurikulum nasional dan disesuaikan dengan kondisi peserta didik. Hal ini 
bahwa peserta didik di sekolah inklusi meskipun mayoritas adalah anak normal namun ada satu peserta didik yang memiliki keterbelakangan mental.

Perencanaan adalah menentukan apa yang akan dilakukan. Perencanaan mengandung rangkaian-rangkaian putusan yang luas dan penjelasan-penjelasan dari tujuan, penentuan kebijakan, penentuan program, penentuan metode-metode dan prosedur serta kegiatan berdasarkan jadwal sehari-hari (Abdul Majid, 2015). Perencanaan pembelajaran yang harus dipersiapkan anatara lain: memahami kurikulum, menguasai bahan ajar, menyusun program pengajaran, menyusun alat penilaian yang telah dilaksanakan, dan tentunya menetapkan standar minimum kelulusannya (Hidayat, 1990). Guru juga menyiapkan bahan ajar yang sumbernya dari buku siswa serta dari sumber lainnya yang sesuai dengan kebutuhan dan pengembangan pembelajaran peserta didik. Sekolah adalah penyelenggara proses pembelajaran secara otomatis dan berkelanjutan. Guru diharapkan menyelenggarakan pembelajaran yang mampu memfasilitasi semua kebutuhan belajar peserta didik. Berikut ini temuan Rencana Pelaksanaan Pembelajaran yang diterapkan di SDN Sawojajar 01.

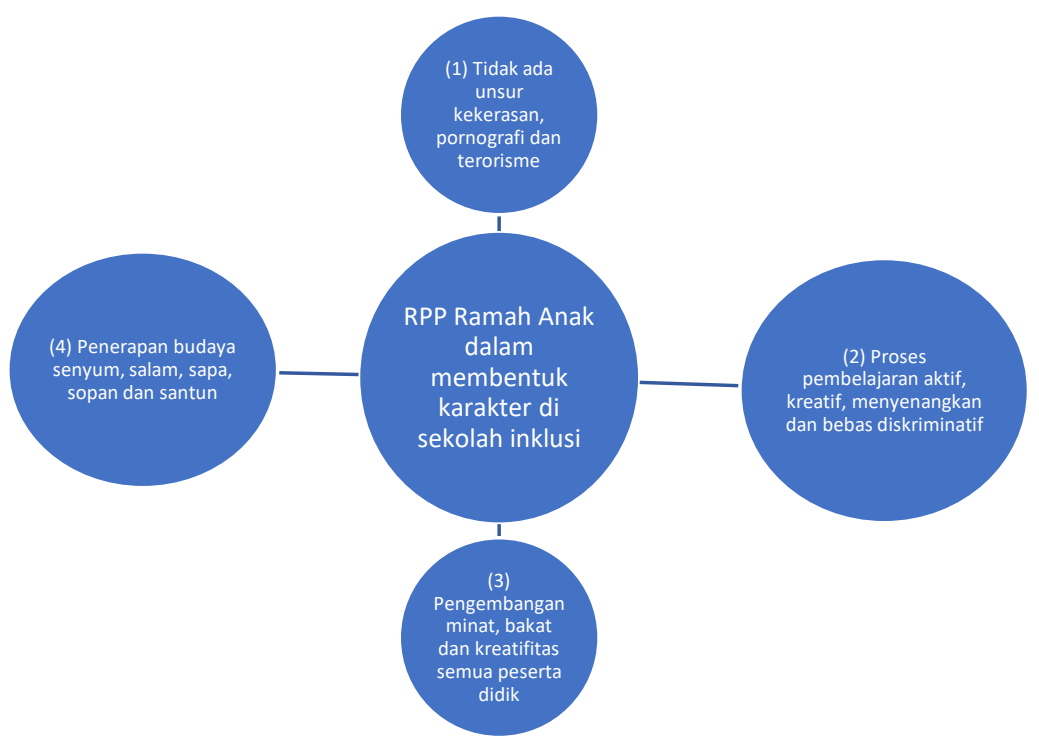

\section{Gambar 1. RPP ramah anak dalam membentuk karakter siswa}

Perilaku terpelajar ditampilkan dalam bentuk pencapaian prestasi akademik, menunjukkan perilaku yang beretika dan berakhlak mulia, memiliki motivasi belajar yang tinggi, kreatif, disiplin, bertanggung jawab, serta menunjukkan karakter diri sebagai warga masyarakat, warga negara dan bangsa. Sekolah harus dapat menciptakan suasana yang kondusif agar anak didik merasa nyaman dan dapat mengekspresikan potensinya. Agar tercipta suasana kondusif tersebut, maka ada beberapa aspek yang perlu diperhatikan, terutama: Perencanaan program sekolah yang sesuai dengan tahap-tahap pertumbuhan dan perkembangan anak didik. Anak tidak harus dipaksakan melakukan sesuatu, tetapi dengan program tersebut anak secara otomatis terdorong untuk mengeksplorasi dirinya. Faktor penting yang perlu diperhatikan sekolah adalah partisipasi aktif anak terhadap berbagai kegiatan yang diprogramkan, namun sesuai dengan kebutuhan anak.

Lingkungan sekolah yang kondusif tercipta jika suasana di lingkungan sekolah menumbuh-kembangkan potensi anak karena anak dapat mengekspresikan dirinya secara leluasa sesuai dengan dunianya. Di samping itu, penciptaan lingkungan yang bersih, akses air minum yang sehat, bebas dari sarang kuman, dan gizi yang memadai merupakan faktor yang penting bagi pertumbuhan dan perkembangan anak. 
Aspek sarana-prasarana yang memadai, terutama yang berkaitan dengan kebutuhan pembelajaran anak didik. Sarana-prasarana tidak harus mahal tetapi sesuai dengan kebutuhan anak. Adanya zona aman dan selamat ke sekolah, adanya kawasan bebas reklame rokok, pendidikan inklusi juga merupakan faktor yang diperhatikan sekolah. Penataan lingkungan sekolah dan kelas yang menarik, memikat, mengesankan, dan pola pengasuhan dan pendekatan individual sehingga sekolah menjadi tempat yang nyaman dan menyenangkan.

Sekolah juga harus menjamin hak partisipasi anak. Adanya forum anak, ketersediaan pusat-pusat informasi layak anak, ketersediaan fasilitas kreatif dan rekreatif pada anak, ketersediaan kotak saran kelas dan sekolah, ketersediaan papan pengumuman, ketersediaan majalah atau koran anak. Sekolah hendaknya memungkinkan anak untuk melakukan sesuatu yang meliputi hak untuk mengungkapkan pandangan dan perasaannya terhadap situasi yang memiliki dampak pada dirinya. Sekolah yang ramah anak merupakan institusi yang mengenal dan menghargai hak anak untuk memperoleh pendidikan, kesehatan, kesempatan bermain dan bersenang, melindungi dari kekerasan dan pelecehan, dapat mengungkapkan pandangan secara bebas, dan berperan serta dalam mengambil keputusan sesuai dengan kapasitas mereka. Sekolah juga menanamkan tanggung jawab untuk menghormati hak-hak orang lain, kemajemukan dan menyelesaikan masalah perbedaan tanpa melakukan kekerasan.

\section{Implementasi pembelajaran ramah anak}

Pembelajaran diartikan membelajarkan siswa menggunakan asas pendidikan maupun teori belajar yang merupakan penentu utama keberhasilan pendidikan (Sagala, 2011). Pelaksanaan kurikulum dan proses belajar mengajar yang ramah anak mulai dari anak masuk gerbang sekolah hingga pulang sekolah, termasuk hingga selesai kegiatan ekstrakurikuler. Adapun komponen indikator ini diantaranya: (1) adanya dokumen kurikulum di satuan pendidikan yang berbasis hak anak; (2) adanya rencana pelaksanaan pembelajaran (RPP) yang ramah anak (antara lain tidak mengandung unsur kekerasan, pornografi dan terorisme); (3) adanya Proses pembelajaran yang aktif, kreatif dan menyenangkan (PAKEM) serta bebas dari perlakuan diskriminatif, pemberian sanksi dan hukuman yang bisa membuat peserta didik merasa mendapat kekerasan baik fisik maupun psikis; (4) adanya kegiatan ekstrakurikuler dan kegiatan siswa lainnya untuk pengembangan minat, bakat dan kreatifitas peserta didik; (5) adanya budaya senyum, salam, sapa, sopan dan santun bagi semua warga sekolah. Hal ini sebagaimana Panduan Sekolah Ramah Anak (2015), bahwa pembelajaran sekolah ramah anak harus ada partisipasi anak, yaitu: peserta didik bisa memilih kegiatan ekstra kurikuler sesuai dengan minat.

Dalam kegiatan pembelajaran di SDN Sawojajar 01 Brebes dilengkapi dengan beberapa sarana dan prasarana pembelajaran, antara lain: (1) sarana dan prasarana yang mendukung pemenuhan hak anak serta ramah anak; (2) adanya ruang kelas yang memiliki kapasitas sesuai jumlah peserta didik, memiliki ventilasi yang cukup dan penerangan yang baik; (3) adanya ruang UKS yang sesuai standar dan digunakan oleh peserta didik; (4) adanya ruang perpustakaan yang memadai dan digunakan aktif oleh peserta didik; (5) adanya ruang konseling bagi peserta didik; (6) adanya kantin sehat yang berada di dalam lingkungan sekolah (tidak berada di luar pagar sekolah); (7) adanya ruang bermain, ruang kreativitas dan sarana olahraga bagi peserta didik; (8) adanya toilet yang bersih dan aman, jumlahnya memadai dan terpisah laki-laki dan perempuan serta tersedia tempat sampah untuk toilet perempuan; (9) adanya tempat cuci tangan pakai sabun (CTPS) di beberapa suduk sekolah; (10) adanya tempat sampah yang terpilah di depan setiap ruang kelas; (11) adanya slogan, papan himbauan dan peringatan kebijakan-kebijakan sekolah di tempat-tempat yang terlihat oleh seluruh warga sekolah. Sebagaimana bahwa guru dalam menciptakan lingkungan belajar guru mengontrol peserta didik, menciptakan komunikasi di kelas, menghargai semua peserta didik, melibatkan dan 
memberikan dukungan kepada semua peserta didik selama kegiatan belajar mengajar dan menerapkan pemecahan masalah, serta keseimbangan dan bertanya dan mendengarkan jawaban peserta didik (Marno \& Supriyanto, 2008). Program sekolah ramah anak memberikan pengaruh sebesar 0,409 terhadap karakter anak usia dini, sedangkan 59,1\% karakter anak usia dini dipengaruhi oleh faktor lain (Nuraeni, Andrisyah, \& Nurunnisa, 2019).

Proses pembelajaran merupakan kegiatan yang dilakukan pendidik dan peserta didik dalam mentransfer ilmu. Dalam kegiatan belajar mengajar dengan konsep ramah anak pembelajaran berpusat pada siswa. Siswa berperan aktif dalam pembelajaran, guru tidak lagi menjadi satu satunya sumber belajar. Guru hanya sebagai fasilitator dalam kegiatan pembelajaran. Hal tersebut sesuai dengan hasil penelitian Yuliasih (2012) bahwa dalam sekolah ramah anak, siswa berada dalam pusat proses pembelajaran. Anak terlibat dalam kegiatan belajar yang mendukung pencapaian mereka dari hasil belajar. Guru memberikan dukungan, instruksi, dan umpan balik (Yuliasih, 2012). Berdasarkan hasil observasi yang dilakukan peneliti dalam proses pembelajaran guru menggunakan metode ceramah dalam menjelaskan materi baru. Selain itu guru juga menggunakan metode tanya jawab, siswa di berikan kesempatan untuk bertanya hal-hal yang belum mereka pahami dari materi tersebut. Sebelum pelajaran di mulai guru menyampaikan tujuan pembelajaran yang akan di pelajari. Untuk memperjelas materi yang disampaikan guru menggunakan internet. Siswa diperlihatkan video atau gambar sesuai dengan materi yang sedang di pelajari. Siswa terlihat senang dalam kegiatan pembelajaran.

Bahan ajar merupakan salah satu bagian terpenting dalam kegiatan pembelajaran. Bahan ajar yang digunakan sesuai dengan kebutuhan dan perkembangan peserta didik. Sumber belajar yang digunakan yaitu buku, internet, dan lingkungan sekitar. Menurut Yulianto (2016) dalam penelitiannya di SDIT Nur Hidayah Surakarta, bahwa pelaksanaan pembelajaran ramah anak menggunakan buku yang di gunakan oleh guru kelas selain buku dari pemerintah, guru-guru juga menggunakan buku-buku dari luar sekolah sebagai referensi tambahan. Buku tersebut sesuai dengan materi yang akan di ajarkan. Selain sumber belajar, media pembelajaran juga berpengaruh dalam kegiatan mentransfer ilmu. Media pembelajaran yang digunakan aman untuk anak-anak. Guru sangat dekat dengan siswa seperti dengan anaknya sendiri, sehingga siswa tidak merasa takut.

Proses pembelajaran di sekolah ramah anak SDN Sawojajar 01 Brebes dilaksanakan secara interaktif antara guru dan peserta didik, inspiratif, menyenangkan, menantang, dan memotivasi peserta didik untuk berperan aktif serta memberikan ruang yang cukup bagi prakarsa, kreativitas, dan kemandirian sesuai dengan bakat, minat, perkembangan fisik serta psikologis peserta didik. Nilai-nilai pokok yang dicontohkan kepala sekolah adalah: disiplin dalam bekerja, mengasuh bawahan, keluarga, tanggung jawab terhadap tugas, dan menerapkan budaya $3 \mathrm{~S}$ senyum, salam, sapa (senyuman, salam, sapa) kepada guru dan siswa (Toharudin \& Ghufroni, 2019).

Pembelajaran aktif, kreatif, efektif, menyenangkan memberikan bantuan berupa sandang seperti seragam, sepatu, tas, buku dan lain-lain. Pangan seperti pemberian makanan tambahan anak sekolah (PMTAS), kesehatan, dan pendidikan yang memadai bagi anak. Selain itu memberikan ruang kepada anak untuk berkreasi, berekspresi, dan partisipasi sesuai dengan tingkat umur dan kematangan nya, memberikan perlindungan dan rasa aman bagi anak, menghargai keberagaman dan memastikan kesetaraan keberadaan, perlakuan adil bagi murid laki-laki dan perempuan, cerdas lemah, kaya miskin, normal cacat dan anak pejabat dan buruh, penerapan norma agama, sosial dan budaya setempat, kasih sayang kepada peserta didik, memberikan perhatian bagi mereka yang lemah dalam proses belajar karena memberikan hukuman fisik maupun non fisik bisa menjadikan anak trauma, saling menghormati hak-hak anak baik antar murid, antar tenaga kependidikan serta antara tenaga kependidikan dan murid, 
terjadi proses belajar sedemikian rupa sehingga siswa merasa senang mengikuti pelajaran, tidak ada rasa takut, cemas dan was-was, tidak merasa rendah diri karena bersaing dengan teman lain, membiasakan etika mengeluarkan pendapat dengan tata cara.

\section{Evaluasi Pembelajaran Ramah Anak}

Evaluasi adalah proses yang sistematis dan berkelanjutan untuk mengumpulkan, mendeskripsikan, menginterpretasikan, dan menyajikan informasi tentang suatu program untuk dapat digunakan sebagai dasar membuat keputusan. Evaluasi dilakukan oleh tim pengembangan model sekolah ramah anak Kabupaten Brebes dan tim pengembangan model sekolah ramah anak di masing-masing satuan pendidikan sebagai berikut: (1) Evaluasi pelaksanaan pengembangan model sekolah ramah anak dilakukan oleh tim pengembangan model sekolah ramah anak di masing-masing satuan pendidikan 3 (tiga) bulan sekali. Hasil evaluasi didokumentasikan untuk dilaporkan kepada tim pengembangan model sekolah ramah anak setiap 6 (enam bulan sekali); (2) Evaluasi pelaksanaan pengembangan model sekolah ramah anak dilakukan oleh tim pengembangan model sekolah ramah anak Kabupaten Brebes di seluruh satuan pendidikan 6 (enam) bulan sekali. Hasil evaluasi didokumentasikan untuk dilaporkan kepada Koordinator Kluster IV Gugus Tugas KLA Kabupaten Brebes yaitu Dinas Pendidikan Pemuda dan Olahraga Kabupaten Brebes 1 (satu) tahun sekali. (3) Laporan hasil evaluasi pelaksanaan pengembangan model sekolah ramah anak akan dievaluasi kembali oleh Kluster IV Gugus Tugas KLA Kabupaten Brebes untuk dilakukan evaluasi dan perbaikan program dan kegiatan pemerintah daerah untuk mendukung pelaksanaan pengembangan model sekolah ramah anak di Kabupaten Brebes.

Evaluasi merupakan serangkaian kegiatan atau aktivitas yang bertujuan untuk mengukur tingkat keberhasilan pada suatu program pendidikan. Evaluasi /atau penilaian merupakan proses untuk mengetahui pencapaian hasil belajar siswa. Penilaian yang diambil bukan dari hasil akhir siswa dapat menyelesaikan suatu masalah, melainkan dari proses mengerjakan atau menyelesaikan suatu masalah (Arikunto, 2009). Berdasarkan hasil observasi yang dilakukan peneliti penilaian yang dilakukan SD Negeri Sawojajar 01 Brebes berupa penilaian otentik. Penilaian otentik merupakan penilaian yang menilai segala aspek yaitu aspek pengetahuan (kognitif), keterampilan (psikomotorik), sikap (afektif) dan spiritual. Penilaian pengetahuan diambil dari ulangan harian, ulangan subtema, Penilaian Tengah Semester, dan Penilaian Akhir Semester. Ulangan subtema dilakukan setiap satu minggu sekali. Penilaian sikap diambil dari observasi guru terhadap keseharian siswa. Penilaian keterampilan diambil dari observasi dan tugas-tugas seperti membuat kerajinan dan poster. Sedangkan penilaian spiritual diambil dari observasi guru dan penilaian antar teman. Penilaian antar teman dilakukan dengan siswa diminta untuk mengisi tabel penilaian yang ditempel di dinding.

Standar penilaian pendidikan merupakan standar nasional pendidikan mekanisme prosedur dan instrumen penilaian hasil belajar peserta didik. Tata tertib guru dipajang agar peserta didik dapat membacanya. Sanksi yang diberikan kepada peserta didik yang melanggar tata tertib, disepakati guru, peserta didik dan orangtua pada awal tahun ajaran baru. Penerapan konsekuensi logis bagi pelanggar tata tertib, misalkan penerapan poin, pemberian reward, disosialisasikan kepada seluruh warga sekolah memberikan reward bagi peserta didik berprestasi baik akademik maupun non akademik. Memberikan bimbingan dan motivasi kepada peserta didik yang kurang berhasil dalam evaluasi. Implementasi program sekolah ramah anak guru tidak mempermalukan peserta didik di hadapan teman-temannya. Guru secara transparan menjelaskan kepada peserta didik kriteria penilaian. Mengoreksi dan menilai pekerjaan rumah. Anak diberi kesempatan menilai kinerja guru. 


\section{Simpulan}

Berdasarkan hasil penelitian dapat disimpulkan bahwa manajemen pembelajaran ramah anak di SDN Sawojajar 01 Brebes, terjadi melalui beberapa proses (1) Perencanaan pembelajaran ramah anak, yang dilaksanakan dalam bentuk penyusunan RPP yang ramah anak oleh guru. RPP tersebut sesuai dengan pembelajaran yang dibutuhkan oleh anak dan tidak mengandung unsur kekerasan, pornografi dan terorisme; (2) Pelaksanaan pembelajaran, yang ditandai dengan berlangsungnya proses pembelajaran yang aktif, kreatif dan menyenangkan (PAKEM) bebas dari perlakuan diskriminatif, adanya kegiatan ekstrakurikuler dan kegiatan pengembangan minat, bakat dan kreatifitas peserta didik, dan tidak adanya hukuman yang merugikan kondisi fisik dan mental siswa; (3) Evaluasi pembelajaran, evaluasi dilakukan oleh guru untuk mengukur kemampuan belajar peserta didik dengan memperhatikan kadar pencapaian tujuan, mengetahui tingkat penguasaan siswa, dan memberikan nilai kepada siswa sebagai laporan hasil belajar di sekolah tanpa diskriminasi; (4) upaya untuk meningkatkan pembelajaran ramah anak di SDN Sawojajar 01 yaitu dengan membudayakan 5S, yaitu: senyum, sapa, salam, sopan dan santun. Selain itu juga menerapkan $7 \mathrm{~K}$, yaitu : keamanan, ketertiban, kegotongroyongan, kebersihan, keindahan, kekeluargaan, dan kerindangan.

\section{Rujukan}

Arikunto, S. (2009). Dasar-Dasar Evaluasi Pendidikan. Jakarta: Bumi Aksara.

Bungin, B. (2011). Penelitian Kualitatif. Jakarta: Prenada Media Group.

Direktorat Pendidikan Luar Biasa. (2007). Pedoman Umum Pendidikan Inklusi. Jakarta: Kemendikbud RI.

Hidayat, H. (1990). Strategi Belajar Mengajar Bahasa Indonesia. Bandung: Bina Cipta.

Kementrian Pemberdayaan Perempuan dan Perlindungan Anak (KPPPA) Republik Indonesia telah mengeluarkan Peraturan Menteri Negara Pemberdayaan Perempuan dan Perlindungan Anak Nomor 11 Tahun 2011 tentang Kebijakan Pengembangan Kabupaten/ Kota Layak Anak (KLA)

Kementerian Pemberdayaan Perempuan dan Perlindungan Anak Republik Indonesia. (2015). Panduan Sekolah Ramah Anak

Majid, A. (2015). Strategi Pembelajaran. Jakarta: Kencana

Marno, M., \& Supriyanto, T. (2008). Manajemen dan Kepemimpinan Pendidikan Islam. Malang: PT. Refika Aditama.

Mulyasa, E. (2009). Menuju Kepala Sekolah Profesional. Bandung: Ganesha.

Nuraeni, L., Andrisyah, A., \& Nurunnisa, R. (2019). Efektivitas Program Sekolah Ramah Anak dalam Meningkatkan Karakter Anak Usia Dini. Jurnal Obsesi: Jurnal Pendidikan Anak Usia Dini, 4(1), 20-29.

Sagala, S. (2011). kemampuan ProfesionalGuru dan Tenaga Kependidikan, Alfabeta,Bandung. 70-71.

Suharno, S. (2008). Manajemen Pendidikan, Sebuah Pengantar Bagi Para Calon Guru. Surakarta: LPP UNS dan UNS Press.

Toharudin, M., Florentinus, T. S., Ekosiswoyo, R., \& Sutarto, J. (2018). The Increase in ChildFriendly Learning Management towards the Formation of Students' Character in Inclusive Elementary School. Journal of Physics: Conference Series, 1254(1), 12-52.

Toharudin, M., \& Ghufroni, G. (2019). Leadership of The Headmaster in Managing Inclusive Elementary School in Brebes Regency. Educational Management. Educational Management, 8(2), 173-182. 
Valeo, A. (2008). Inklusive Education Supprot System: Teacher and Administrator Views. International Journal of Special Education, 23(2), 44-55.

Yuliasih, K. (2012). Implementasi Program Sekolah Ramah Anak di SD Putren Pleret Bantul dalam Spektrum Analisis Kebijakan Pendidikan. Jurnal Penelitian Pendidikan FIP UNY, 1(1), 1-10. 